\title{
Modern Combined Effect of Concentration of Common Salt and Liquid Smoke on the Microbial Quality of Solar Dried Tilapia
}

\author{
Felix Adom Telfer ${ }^{1}$, Paul Goddey Gablah ${ }^{2,}{ }^{*}$, Henry Afealetey ${ }^{3}$, Maxwell Takyi ${ }^{3}$, Gloria Asare ${ }^{4}$ \\ ${ }^{1}$ Department of Food Processing Engineering, University of Ghana, Legon, Accra, Ghana \\ ${ }^{2}$ Department of Research and Innovation, Accra Technical University, Accra, Ghana \\ ${ }^{3}$ Science Laboratory Department, Accra Technical University, Accra, Ghana \\ ${ }^{4}$ Purchasing and Supply Department, Accra Technical University, Accra, Ghana
}

Email address:

adomtelfer@gmail.com (F. A. Telfer), Paul4angella@gmail.com (P. G. Gablah), richlandacedemey123@gmail.com (H. Afealetey), maxwelladjei76@gmail.com (M. Takyi),gloasre123@yahoo.com (G. Asare)

${ }^{*}$ Corresponding author

\section{To cite this article:}

Felix Adom Telfer, Paul Goddey Gablah, Henry Afealetey, Maxwell Takyi, Gloria Asare. Modern Combined Effect of Concentration of Common Salt and Liquid Smoke on the Microbial Quality of Solar Dried Tilapia. International Journal of Food Engineering and Technology. Vol. 3, No. 1, 2019, pp. 8-12. doi: 10.11648/j.ijfet.20190301.12

Received: December 31, 2018; Accepted: March 28, 2019; Published: April 22, 2019

\begin{abstract}
The nutrition of the people of developing countries is a major public health issue which has challenged Food Scientist to enhance the nutritional quality of preferred and enrichment how to prepare food. Fish is a major source of protein and its harvesting, handling, processing and distribution provide livelihood for millions of people. This research was done to estimate the microbial quality of solar dried tilapia upon the application of common salt and liquid smoke with different concentrations. Low records of microbial load were determined for each of the fish sample. From the results it was clearly determined that fresh dried fish had a microbial load of $10(1: 10), 8(1: 100)$ and $5(1: 1000)$, dry fish with $100 \mathrm{~g}$ Sodium Chlorine $(\mathrm{NaCl})$ and $0 \mathrm{~mL}$ liquid smoke had a microbial load of 21(1:10), 12(1:100) and 7(1:1000). The combined use of common salt and liquid smoke to process fish had reduction in the moisture content of the final product which significantly reduced the microbial load of the final product. Preservation and processing therefore become a very important part of commercial fisheries. This study is important because it provide information that will guide Fisheries managers to allow for more adaptation to new and easy methods of Processing fish products.
\end{abstract}

Keywords: Consumption, Liquid Smoking, Flavour, Tilapia, Modern Fish, Sensory Control

\section{Introduction}

Consumption of fish provides energy, protein and a range of essential nutrients. Eating fish is part of the cultural traditions of many peoples. In some populations, fish is a major source of food and essential nutrients. Among the general adult population, consumption of fish, particularly fatty fish, lowers the risk of coronary heart disease mortality.

Post-harvest fish lose is the discard of fish after harvest and causes the loss of potential income. It is because of poor processing techniques, animal predation and insect infestation, inadequate packaging and storage and discarding of the fish at sea [1].

Many factors affect this loss. These factors determine the occurrences of many types of postharvest fish lose. These lose are classified as; lose in nutritional value, physical lose, quality lose, market force lose, lose due to traditional processing, lose during distribution and storage, and lose due to insect infestation. Fish that is decomposed to such a degree that it is unfit or unsafe for human consumption is a nutritional loses. Physical fish lose refers to fish that is after capture or landing is not used. It is either complete physical lose or partial lose in materials. Quality lose refers to fish that are undergone changes owing to spoilage or physical damage 
which gives lower price than best quality fish. Technological and infrastructure problems are often cited as cause of Postharvest quality lose [2].

A combination of smoke, salt, and drying is one of the earliest recorded methods of food preservation. These procedures, loosely known as "Smoking" or "Smoke Preservation," are successful because they kill food poisoning and spoilage bacteria or render them harmless by altering the chemistry of the environment these spoilage organisms need to grow. Smoked seafood is prepared with two basic procedures. Hot smoking cooks the product; cold smoking does not. Cold smoking devices have one basic function: to apply smoke to the product. Hot smoking devices have the added function of applying heat. And because preservation of fish usually requires moisture removal, systems designed for hot or cold smoking fish may have the added function of dehydration. Modern fish smoking equipment is usually designed to produce either hot or cold smoked products, but in either case they are usually designed to have adequate airflow and exchange to remove large quantities of water from the product [3]. In the past, people smoked fish with high salt and low moisture content. Lately, producers have adjusted the processing condition to produce lower salt products to fulfill consumer demands [4]. Commercialisation of smoked fish has led to the shift for high sensory quality product which has become the main purpose of smoking. The smoked products have higher moisture and lower salt content than in the past [5]. Liquid smoke flavourings have been used for the preservation of meat and fish for over 40 years [5]. Raw or processed seafood are generally excellent substrates for the growth of most common bacterial agents of food-borne diseases, especially when held at improper temperatures. This can affect the shelf life of seafood. Whiles in fish, the proposed limit of acceptance for human consumption is $7 \mathrm{log} \mathrm{CFU} / \mathrm{g}$ (ICMSF, 1986). The initial quality of the raw material used was good and fit for smoking, as indicated by the low number of bacteria (2.8 $\log \mathrm{CFU} / \mathrm{g})$. The effects of processing technologies, packing materials and storage temperature were observed after smoking. Smoking affects the quality of fish in numerous ways, but this depends largely on the quality of the raw material used. A good quality raw material will yield a good quality smoked product that ensures a steady market demand and profits for the processor [6]. Liquid smoke compositions are obtained from pyrolysis of hardwood.

These solutions are used to impart flavour, colour, and texture and in certain cases provide enhanced shelf life for food products [3]. Sensory quality of smoked fish is affected by raw material, salting method, condition of processing, composition of smoke, smoking method, and smoke agents [7]. Using commercial liquid smoke tended to be higher in lightness, redness, and yellowness but softer than traditional smoked tilapia.

Although the number of bacteria was lower after smoking in liquid smoke product, the high water content of the fish led to growth of bacteria during storage and this made the maximum shelf life of the product at $4^{\circ} \mathrm{C}$ to $5^{\circ} \mathrm{C}$ to be three weeks [7]. To estimate the microbial quality of solar dried tilapia upon the application of common salt and liquid smoke with different concentrations. This research is done to satisfy a need for something new which will help in preserving fish in our society. There are many problems associated with preservation of fish which leads to lose of nutrients due to poor processing techniques and storage of fish. In the past, people smoked fish with high salt and low moisture content. Lately, producers have adjusted the processing condition to produce lower salt products to fulfill consumer demands by using liquid smoke solutions. These solutions are used to impart flavour, colour and texture and in certain cases provide enhanced shelf life for food products. The aim was to determine the effects of combine concentrations of common salt and liquid smoke on solar dried tilapia. The combined use of common salt and liquid smoke to process fish together with reduction in the moisture content of the final product would significantly reduce the microbial load of the final product. The objective was to determine the effects of different concentrations of common salt and liquid smoke on solar dried tilapia and also assess the types and populations of microbes on solar dried tilapia.

\section{Literature}

\subsection{Fish}

Fish is an important source of food and income to many people in the developing world. In Africa, some 5 percent of the population, about 35 million people, depend wholly or partly on the fisheries sector, mostly artisanal fisheries, for their livelihood. Various traditional methods are employed to preserve and process fish for consumption and storage. These include smoking, drying, salting, frying and fermenting and various combinations of these. In Ghana, smoking is the most widely practised method: practically all species of fish available in the country can be smoked and it has been estimated that 70-80 percent of the domestic marine and freshwater catch is consumed in smoked form. The advantages of smoking fish are manifold. Fish smoking prolongs shelf life, enhances flavour and increases utilization in soups and sauces. It reduces waste at times of bumper catches and permits storage for the lean season. It increases protein availability to people throughout the year and makes fish easier to pack, transport and market [8].

Fish smoking in Ghana is traditionally carried out by women in coastal towns and villages, along river banks and on the shores of Lake Volta. In most fishing communities, in fact, the main economic activity of women is fish processing. Depending on the type of fish to be smoked, its uses and possible storage period, the smoking process can take the form of "wet" hot smoking or "dry" hot smoking. Both processes are carried out at temperatures above $80^{\circ} \mathrm{C}$, which are high enough to cook the fish. Until the end of the 1960s, the ovens most used 
for smoking fish in Ghana were cylindrical or rectangular and made of mud or metal. Using these ovens had considerable disadvantages, however, such as excessive handling of fish during smoking, a problem more severe when smoking small species of fish such as anchovies. The ovens had a low capacity, were inefficient in fuel usage and could not cope with the large volumes of fresh fish landed during bumper fish seasons [8].

Ghanaian artisans employ various traditional methods to preserve and process fish for consumption and storage. These methods include smoking, drying, salting, frying and fermenting sun-drying, grilling and frying, and various combinations of these. The predominant type of fishery product in any particular country is, however, closely related to the food habits and purchasing power of the population. Specific types of fishery products are best suited as the local staple food [9].

\subsection{Preservation for Short Duration}

\subsubsection{Chilling}

This is obtained by covering the fish with layers of ice. However, ice alone is not effective for long preservation, because melting water brings about a sort of leaching of valuable flesh contents which are responsible for the flavour. But ice is effective for short term preservation such as is needed to transport landed fish to nearby markets or to canning factories, etc. Here is autolytic enzymic activities are checked by lowering the temperature [10].

\subsubsection{Preservation for Long Time}

When the preservation is required for a long period of time, the fishes are passed through the cleaning, gutting and conservation and storage.

\subsubsection{Dry Salting}

In this process the fish is first rubbed in salt and packed in layers in the tubs and cemented tanks. The salt is applied in between the layers of fishes in the proportion of $1: 3$ to $1: 8$ salt to fish. The proportion of salt to fish varies with the fish since the oily fish require more salt. At the end of $10-24$ hours the fishes are removed from the tubs and washed in salt brine and dried in the sun for 2 or 3 days. Large fish lose about one third and small fish about one half of their dressed weights [10].

\subsection{Demerits of Fish Preservation}

Although the preservation and processing constitute a very important aspect of the fish industry, it has certain drawbacks, as well, particularly with respect to retaining quality of fish flesh these are discussed briefly.

Chilling brings about denaturation of flesh. This is because of ice crystals formed during chilling and causing mechanical damage to the muscles. Cell walls burst, structure gets deformed and the flesh loses much of flavour and taste. The flesh also becomes dehydrated and losses texture. If proper hygienic measures are not taken during the processes like washing, guttation and evisceration, etc. more harm would be done to the preserved material, owing to increase in the bacteria population. Incomplete or poor preservation leads to decarboxylation of histidine of fish flesh into histamine. The latter some other related substances, collectively called saurine, are common causes of food poisoning. Drying reduces weight, nutritive value and the digestibility of the flesh. Excess salting allows growth of salt tolerant bacteria, causing pink eye spoilage of fish flesh. Salting combined with smoking results in loss of protein, about 1 to $5 \%$ due to salting and 8 to $30 \%$ due to smoking. Smoking also accelerates rancidity of fat and so reduces digestibility of fat products. Canning leads to much loss of vitamin B1, panthotenic acid and vitamin $\mathrm{C},[2]$.

\subsection{Advantages and Benefits}

As mentioned before, new advances in smoke generation technology and application alternatives have increased the positive benefits of cold smoking foods. Advantages and benefits associated with smoking foods include environmentally-friendly application techniques, antioxidant potential, sensory control, and antimicrobial properties. Smoke condensates are becoming more widely used compared to gaseous smoke because of better process control of drenching, dipping, or gaseous smoke regeneration to impart consistent quantitative and qualitative attributes of smoke flavor and color. Antioxidant activity of smoke condensates has been extensively documented and results indicate potential to retard lipid oxidation in many meat products [3].

Control of sensory properties of smoke has also been widely researched and documented. In fact, an entire lexicon of new descriptive language has been proposed to describe and evaluate commercial smoke condensate flavor profiles. Antimicrobial properties of smoke condensates add to the advantages and benefits associated with the smoking of foods. Antimicrobial properties of smoke in foods have been documented comprehensively throughout the last fifty years, but most of this work has been on components of naturally deposited smoke [3].

\section{Methodology}

\subsection{Tilapia}

Fresh tilapia (Oreochromisniloticus) was used in this study. The material was harvested by a fisherman from the Weija River in the Greater Accra Region of Ghana. The tilapia was transferred from the riverside in an ice chest containing ice cubes to the laboratory and weighed to get the initial weight.

\subsection{Liquid Smoke}

Already prepared liquid smoke was used.

\subsection{Common Salt}

Granulated salt bought from the market was used. 


\subsection{Preparation of Various Combinations of Salt and Liquid Smoke (Salt - Smoke)}

Common salt and Liquid Smoke (LS) was mixed in the following proportions:

$(0 \mathrm{~g} \mathrm{NaCl}+20 \mathrm{ml} \mathrm{LS}),(100 \mathrm{~g} \mathrm{NaCl}+0 \mathrm{ml} \mathrm{LS}),(80 \mathrm{~g} \mathrm{NaCl}+$ $20 \mathrm{ml} \mathrm{LS}),(100 \mathrm{~g} \mathrm{NaCl}+20 \mathrm{ml} \mathrm{LS}),(120 \mathrm{~g} \mathrm{NaCl}+20 \mathrm{ml} \mathrm{LS})$, $(0 \mathrm{~g} \mathrm{NaCl}+0 \mathrm{ml} \mathrm{LS})$.

The salt and liquid smoke was mixed together in a small bowl to make a mixture resembling moist brown sugar.

\subsection{Cleaning and Brining of Fish}

The fresh tilapia was weighed to get the initial weight. They were gutted by using a sharp knife. The tilapias were washed thoroughly with fresh water to remove all the blood in them. The freshly cleaned tilapias were covered in $10 \%$ sodium chloride $(1 \mathrm{~kg}$ of salt to $9 \mathrm{~L}$ of water) overnight to leach out the blood. After, they were predried to drain most of the water out of them and to make their surfaces dry.

\subsection{Dry Salting}

Starting with a layer of the salt - smoke, alternated layers of salt - smoke and fish was placed in a plastic container. The mixture of saltand liquid smoke was spread all over the surface of the fish sample.

\subsection{Solar Drying}

The salted fish was dried in a solar dryer to constant weight. It took 15 days before most of the fish sample got dried.

\subsection{Microbial Analysis}

Microbial analysis was done on the granulated salt, liquid smoke, then various salt - smokes, fresh tilapia, salted tilapia, fresh dried tilapia and dried tilapia during storage.

The fish sample was pulverized wholly using a blender (maker). Five milliliters was taken from each sample into a sterile bottle containing $450 \mathrm{ml}$ of sterile peptone physiological saline to form a stock culture. The sample bottle was shaken vigorously. 3-fold serial dilutions was prepared with peptone physiological saline.

Aerobic mesophilic bacteria was enumerated on plate count agar at $37^{\circ} \mathrm{C}$ for 24 hours and reported as total viable count (TVC).

Yeasts and moulds was enumerated on yeast extract agar at $25^{\circ} \mathrm{C}$ for 72 hours.

Enterobacteriaceae was enumerated on Violet Red Bile Glucose at $37^{\circ} \mathrm{C}$ for 24 hours.

Staphylococci was enumerated on mannitol salt agar at $30^{\circ} \mathrm{C}$ for 48 hours.

\section{Discussion}

\subsection{Results of Different Count of Fish Samples}

Table 1. A bar chart showing the total viable count for each dilution of each samples.

*Sodium Chloride $(\mathrm{NaCl})$

\begin{tabular}{|c|c|c|c|c|c|c|}
\hline \multirow{2}{*}{ Fish sample } & \multicolumn{3}{|c|}{ Total Viable Count(CFUs /ml) } & \multirow{2}{*}{$\begin{array}{l}\text { Yeast and } \\
\text { Moulds }\end{array}$} & \multirow{2}{*}{ Enterobacteria } & \multirow{2}{*}{ Staphylococci } \\
\hline & 1:10 & $1: 100$ & 1:1000 & & & \\
\hline Fresh fish & 1.9 & 0.11 & $7 \times 10^{\wedge}-3$ & NEGATIVE & NEGATIVE & NEGATIVE \\
\hline Dry fish with $100 \mathrm{~g}$ Nacland $0 \mathrm{~mL}$ liquid smoke & 2.1 & 0.12 & $7 \times 10^{\wedge}-3$ & NEGATIVE & NEGATIVE & POSITIVE \\
\hline Dry fish with $80 \mathrm{~g} \mathrm{NaCl}$ and $20 \mathrm{~mL}$ liquid smoke & 0.9 & 0.05 & $3 \times 10^{\wedge}-3$ & NEGATIVE & NEGATIVE & POSITIVE \\
\hline Dry fish with $100 \mathrm{~g} \mathrm{NaCl}$ and $20 \mathrm{mLliquid}$ smoke & 0.9 & 0.04 & $2 \times 10^{\wedge}-3$ & NEGATIVE & NEGATIVE & POSITIVE \\
\hline Dry fish with $20 \mathrm{mLliquid}$ smoke and $0 \mathrm{~g} \mathrm{NaCl}$ & 0.7 & 0.04 & $2 \times 10^{\wedge}-3$ & NEGATIVE & NEGATIVE & NEGATIVE \\
\hline Granulated salt & 2.7 & 0.19 & $8 \times 10^{\wedge}-3$ & NEGATIVE & NEGATIVE & POSITIVE \\
\hline Liquid smoke & 0.6 & 0.03 & $2 \times 10^{\wedge}-3$ & NEGATIVE & NEGATIVE & NEGATIVE \\
\hline $80 \mathrm{~g} \mathrm{NaCl}$ and $20 \mathrm{~mL}$ liquid smoke & 1.0 & 0.08 & $4 \times 10^{\wedge}-3$ & NEGATIVE & NEGATIVE & POSITIVE \\
\hline $100 \mathrm{~g} \mathrm{NaCl}$ and $20 \mathrm{~mL}$ Liquid smoke & 1.5 & 0.09 & $6 \times 10^{\wedge}-3$ & NEGATIVE & NEGATIVE & POSITIVE \\
\hline $120 \mathrm{~g} \mathrm{NaCl}$ and $20 \mathrm{~mL}$ liquid smoke & 1.9 & 0.12 & $7 \times 10^{\wedge}-3$ & NEGATIVE & NEGATIVE & POSITIVE \\
\hline
\end{tabular}

(Data source, 2018)

\subsection{Discussion}

The use of liquid smoke and salt to preserve fish is very important because it helps to reduce moisture content and also reduce the microbial load of the product.

From the results it was clearly determined that fresh dried fish had a microbial load of 10(1:10), 8(1:100) and $5(1: 1000)$, dry fish with $100 \mathrm{~g}$ Sodium Chloride $(\mathrm{NaCl})$ and $0 \mathrm{~mL}$ liquid smoke had a microbial load of 21(1:10),
12(1:100) and 7(1:1000), dry fish with $80 \mathrm{~g}$ Sodium Chloride $(\mathrm{NaCl})$ and $20 \mathrm{~mL}$ liquid smoke had a microbial load of 9(1:10), 5(1:100) and 3(1:1000), dry fish with 100g Sodium Chloride $(\mathrm{NaCl})$ and $20 \mathrm{~mL}$ liquid smoke had a microbial load of 9(1:10), 4(1:100) and 2(1:1000), dry fish with $120 \mathrm{~g}$ Sodium Chloride $(\mathrm{NaCl})$ and $20 \mathrm{~mL}$ liquid smoke had a microbial load of $8(1: 10), 5(1: 100)$ and $2(1: 1000)$ and dry fish with $20 \mathrm{ml}$ liquid smoke and $0 \mathrm{~g}$ Sodium Chloride $(\mathrm{NaCl})$ had a microbial load of 7(1:10), 4(1:100) and 2(1:1000). And 
also the microbial load of the granulated salt was 27(1:10), $19(1: 100)$ and $8(1: 1000)$, liquid smoke alone had a microbial load of $6(1: 10), 3(1: 100)$ and $2(1: 1000), 80 \mathrm{~g}$ Sodium Chloride $(\mathrm{NaCl})$ and $20 \mathrm{~mL}$ liquid smoke had a microbial load of10(1:10), 8(1:100) and 4(1:1000), 100g Sodium Chloride $(\mathrm{NaCl})$ with $20 \mathrm{~mL}$ liquid smoke had a microbial load of 15(1:10), 9(1:100) and 6(1:1000) and 120g Sodium Chloride $(\mathrm{NaCl})$ with $20 \mathrm{~mL}$ liquid smoke had a microbial load of $19(1: 10), 12(1: 100)$ and $7(1: 1000)$. Staphylococci is a mesophile and therefore are salt tolerant, and this accounted for the growth of staphylococcus on the granulated salt and also the combination of the salt and the liquid smoke.

The combined concentration of common salt and liquid smoke was known to be effective because low records of Total Viable Count (TVC) was determined. A Total Viable Count is achieved by plating dilutions of culture until 30 to 300 colonies exist on a single plate. Total Viable Count gives a quantitative idea about the presence of microorganisms such as bacteria, yeast and moulds in a sample. A high Total Viable Count, count is usually attributed to poor quality. In Food Microbiology it is used as a benchmark for the evaluation of the shelf life of food stuffs. Its scope is as an assessment tool rather than focus towards a specific organism.

\section{Conclusion}

The findings of current research are useful for developing and improving the quality of functional products developed by food process industries. Essential nutrients required by the human body can be fulfilled from fish, which is one of the rich sources of major and minor food supplements. The combined effect of common salt and liquid smoke to process fish will lead to reduction in moisture content and also significantly reduce the microbial load of the final product. Fish processing is still predominantly undertaken manually in Ghana. Traditional fish processors adopted open fire or simple smoking oven. Such as mud or halved cut drum oven. The different types of fish preservation techniques observed were salting/smoking, smoke drying, liquid smoking, frying and sun drying. The raw material characteristics are of great importance for the yield and product quality.

\section{References}

[1] Salonen. K., Sarvala. J. (1995). Field manual for determination of chlorophyll and primary production inlake Tanganyika. research FAO/FINNIDA. Research for the management of fishies on lake Tanganyika. GCP/RAF/27/FN/18(EN):27pp.

[2] Harris, W. S., Mozaffarian, D., Lefevre, M. Toner, C. D., Colombo, J., Cunnane, S. C., Holden, J. M., Klurfeld, D. M., Morris, M. C. \& Whelan, J. 2009. Towards establishing dietary reference intakes for eicosapentaenoic anddocosahexaenoic acids. Journal of Nutrition, 139:804819.

[3] Maga, J. (1988). Smoke in Food Processing. Boca Raton, Florida: CRC Press, Inc.

[4] Kenneth. S, Hilderbrand, Jr. Quick Determination of Water Phase Salt Content of Smoked Fish. ORESU-I-00-003 (was Special Report 883) Revised November 21, 2000.

[5] Hattula, T., Elfving, K., Mroueh, U., and Luoma, T. (2001). Use of Liquid Smoke Flavouring as an Alternativeto Traditional Flue Gas Smoking of Rainbow Trout Fillets (Oncorhynchusmykiss). Lebensmittel-Wissenschaft undTechologies, 34, 521-525.

[6] Cardinal, M., Knockaert, C., Torrissen, O., Sigurgisladottir, S., Morkore, T., Thomassen, M., \&Vallet, J. L. (2001). Relation of smoking parameters to the yield, colour and sensory quality of smoked Atlantic salmon (Salmosalar). Food Research International 34(6): 537-550.

[7] Huong, D. T. (2013). The effect of smoking methods on the quality of smoked mackerel. Final Project. Reykjavik: United Nations University Fisheries Training Programme.

[8] Daramola, J. A.; Fasakin, E. A. and Adeparusi, E. O., (2007). Changes In Physicochemical And Sensory Characteristics Of Smoke-Dried Fish Species Stored At Ambient Temperature, African Journal of Food Agriculture Nutrition and Development, 7, 6.

[9] Pace, R. D., Plahar, W. A, and Lu, J. Y., (1989). Status of Traditional Food Preservation Methods for Selected Ghanaian Foods. Food Reviews International, 3(1), 1-12.

[10] FAO, (2001). Example of successful in agriculture and rural development in the south. Sharing innovative experience 5, 240-254. 